\title{
Mythos Politicus: A Theoretical Framework for the Study of Political Myths
}

\begin{abstract}
By Ramy Magdy*
The relationship between myth and politics is widely studied in social sciences, mythology and political science. However, the diverse literature on the politics/myth engagement neither offered a comprehensive study for understanding the different instances of the myth/politics engagement, nor tried to offer any analytical framework for analyzing political myths into political realities. Part of this inadequacy might be attributed to the multifaceted nature of both of the political and the mythological phenomena and the other part is due to the variety of shapes that political myths might take. For this reason, this paper aims from exploring the literature on the myth/politics engagement at offering a general theory for the study of political myth by exploring its different instances. Out of these instances and by focusing on one type of political myths which is the foundation narrative the paper will try to offer an analytical framework for the study of political myth into political reality. Foundation narrative is chosen due to its revelatory character of the different values political founders cherish and its ability to explore their vision for the future. This makes the concept of political myth of a practical importance to judge the consistency of politicians' discourses and explore their vision for future. Focusing on Egypt, the paper will try to apply its analytical framework to analyze the different foundation narratives of the Egyptian state and the crisis of its current foundation narrative.
\end{abstract}

Keywords: Egypt, Myth, Politics, Foundation, Narrative, State.

"Faust: I write, in the beginning was the Deed!"

Goethe (1808) Faust Part I

\section{Introducing the Theory of Political Myth}

Political mythology is a rich field. It studies, mainly, how politics formulates myth and how myth influences political actions. As a matter of fact, a theory for such a topic cannot be outlined perfectly in one single paper or a book. Yet introducing its main definitions, features, approaches, circumstances, and functions is a necessary task to be undertaken, if one wants to understand the myth/politics engagement. From such a task the concept of foundation narrative could be understood and a proper usage of the concept could be made in studying the Egyptian case.

\footnotetext{
*Assistant Lecturer, Faculty of Economics and Political Science, Cairo University, Egypt.
} 


\section{Terminology and Definitions}

Myth comes from the word mythos that stands in Greek for the revealed, declared sacral words, that's why myth differs from the mere logos which also means 'word' (Stevanovic 2008: 26). The word mythos signifies an authoritative statement about something revealed or sacral, while logos represents a word of truth reached by reason through evidence and augmentation (Stevanovic 2008: 28). Myth is the divine address of men. It is the story of the absolute truth and the representation of 'the Reality' in the words of gods in some metamorphosis figurative and ambiguous manner (McDonald 1969: 141).

Definitions of myth are diverse and many. Oxford dictionaries defines myth as "a usually traditional story of ostensibly historical events that serves to unfold part of the world view of a people or explain a practice, belief, or natural phenomenon" (Oxford 2016).While Cambridge online dictionary defines myth as 'an ancient story or set of stories, especially explaining the early history of a group of people or about natural events and facts' (Cambridge 2016). Scholars also vary over the definition of myth. Schorer argues that 'a myth is a large, controlling image that gives philosophical meaning to the facts of ordinary life; that is, which has organizing value for experience' (Schorer 1959: 360). Claude Levi-Strauss defines myth as 'language, functioning on an especially high level where meaning succeeds practically at [taking off] from the linguistic ground on which it keeps on rolling' (Levi-Strauss 1963: 210). While Mircea Eliade defines myth as, 'always an account of creation, ... a dramatic breakthrough of the sacred' (Eliade 1998: 5-6), and he argues that:

the myth components are (1) the history of the deeds of the supernatural being (2) that history is considered to be completely truthful because it refers to the real and sacred since supernatural beings have made it (3) myth always regards to the 'creation' it shows how something started to exist or how a way of life, an institution, and way of work had started. consequently, myths creates the beginning of every significant human act, by knowing myth one knows the source of things, which one can also outpower and manipulate by his free will, it is not about the external abstract cognition but about a cognition expressed through rituals by solemn telling of stories or through performing the rite to whom it serves as a cause (5) the purpose is that myth, through a way or another, has to be experienced so that every one can be possessed by the sacred devastating power of events that it evokes and lives again' (Eliade 1963).

While Frankfort claims that:

'myth is the form of poetry that transcends poetry by declaring one truth, a form of thinking that transcends thinking by wishing to reach the truth that it declares, myth is a form of action, ritual attitude that doesn't realize itself in the act but has to be declared and pronounced in the poetic form of truth' (Stevanovic 2008: 28).

On the other hand, Political myth can be defined as 'a work on a common narrative which grants significance to the political conditions and experiences of a social group' (Benoit and Bottici 2010: 16), while Flood maintains that 'a 
working definition of political myth would be; an ideologically marked narrative which purports to give a true account of a set of past present or predicted political events and which is accepted as valid in its essentials by a social group' (Flood 1996: 44).

From the above, political myth reflects an account that claims to be the transcendent absolutely truthful story about politics. It targets social groups and communicates to them some standard of significance/insignificance so they can judge political experiences. Hence political myth has an account of how things started to be, a target group and criteria for judgment. Established on these, the author argues for his concept of 'foundation narrative'. The foundation narrative is the political myth narrating the foundation story of a state or republic or a regime and the values that should be learnt from it. Such a story not only describes the narrative of the founders, but also gives a clue about their vision for the future. It is mythological since it represents itself as the ultimate truthful account of history and the origins of things, and it uses unconventional language to communicate the values it preaches for the future. But to understand foundation narrative as a political myth, one has to understand political myth better by understanding its different features.

The Features of Myth

Myth regardless of its different manifestations in politics, society and religion, and inspite of the inability to draw a line among its various manifestations in these spheres, mythological accounts have common features that myth reveals itself through.

\section{Myth Claims the Truth}

Myth by its claim to know the story of things and the revelation of the absolute declares that its account is not to be judged as either truthful or false, because simply it is 'The Truth' and its details represent the elements of truth. That's why myth not only gives an account about the reality of things but also it enables an orientation inside the world by providing its believers with absolute standards for conceiving and evaluating things (Stevanovic 2008: 29). Mythological accounts do not speak about everyday life but about the crucial existential issues in life of and human relationship with the world. They explain to man why he had experienced something and what can he expect from the future (Stevanovic 2008: 29). In addition, the mythological claim of truth and its judgmental power give a sense to the world and offer positiontionalies and values that are moral, anthropological and human. Consequently, myth cannot be verified or justified because it gives the very criteria for verification and justification and in turn cannot be verified by them (Stevanovic 2008: 30, Morong 1994). Moreover, myth speaks in total, it explains the totality of things, the time before time, and it has its own causal relations between its elements, 'it freely chooses causes' (Stevanovic 2008: 27). That's why mythological accounts are very fundamental, total, absolute, justifying but cannot be justified. 


\section{Myth Has a Unique Relation with Time and History}

Myth by its nature has a unique relation with time and history. Political myth, and myths in general, can be considered ahistorical/atemporal in the sense that they lie outside the chronology of time since they dictate their own chronology. Yet offering such 'different' a chronology does not make a myth non historical or not temporal because this might represent a judgment on myth by a chronology it did not offer. Myth cannot be judged as historical or not historical because simply they narrate their own story of history. Myth stands outside history and draws a chronology of its own. Consequently, such chronology cannot be judged by any other chronology. Myth is fundamental in this regard.

Myths are a historical/atemporal because they are stories about the beginnings and origins which nothing is to be perceived before or outside (Stevanovic 2008: 29). Nevertheless, myths are also historical and temporal by their interest in offering accounts for histories and temporal chronologies. Myth not only narrates the past and how things started, but also this start that myth narrates determines how the future would look like (Stevanovic 2008: 31). That's why myth is uniquely able to 'bridge old and new, the past and future, to absorb new meanings and to give structure to the inchoate', and more importantly, to 'declare prophecies' (McDonald 1969: 143). However, this mythological appeal to the past and the beginnings of things does not mean merely conservatism but a yearning to some perfect situation which need not to have ever existed before. It only represents an ideal way of life that guides the myth targets to reform their living and take future actions. This proves why the mythological relation to the past does not mean simply replication of the old (Stevanovic 2008: 31).

\section{Myths are Symbolical Constructs}

Due to the 'arational' nature of mythos, it tends to comprehend and judge realities by measuring their conformity to a fundamental construct it creates. This construct represents the divine, the absolute and the original. It is the truth myth stands to claim. Such a construct is formulated into symbols, these symbols evoke emotional feelings in the target groups and represent to some extent some of their cherished values. Symbols by relating themselves to emotions can start to give meanings of what is good, bad, ugly, etc. This symbols/emotions relationship formulates the construct. Myth defines its different elements and narrate itself by using symbols invoking emotional feelings and absolute definitions. The choice of these feelings and definitions must somehow respect the emotional criteria of judgment in the target group, otherwise myth will gain no ground and will appear as alien. Therefore, each myth includes symbols for what is the good, the bad and the enemy. Such symbols are absolute and unjustified except in the feelings of respect, awe and disgust held by the target group. The uneasiness or the absence of an emotional-base welcoming such a construct in the target group might render myth senseless. For this reason, myths usually offer symbols welcomed emotionally, and by their judgmental power based on that constructs, can give sense to the huge data one receives daily by 
his senses from the world. The relation between these symbols reveals how myth wishes the orientation of man towards the world and other men to be. These symbols 'define the geography, topography of everyone political world' (Stevanovic 2008: 34).

\section{The Human Role in the Mythological Drama}

The divine word, the stor(ies) of origins and the prophec(ies) of destiny cannot be accepted in the human world without some role given to men. The cosmic drama can never be understood without some role for man. The role of human beings in myth usually takes the form of a mythical ruler/founder/hero, and a chosen group or people. This hero, through some divine mythical mission, is sent to save the nation, conquer challenges, destroy the corrupt order and either start the new better order or renovate the community (Stevanovic 2008: 37, McDonald 1969: 144). Accompanying this political ruler/hero is the chosen people that solely represent the heroic act of victory and foundation, or receive the divine mission on the hands of the mythical ruler. So the chosen people are either the founder or the followers of the founder. In both cases they are destined to engage into some heroic and divine mission (Tamse 1975: 17).

\section{Myth as a Concept is Indestructible}

Myth gives sense to the world because at the very base of every category of judgment there is some symbols related to some myth that claims to represent the truth and knowledge of the origins (McDonald 1969: 143). Myth is the fountain of truth. Truths, no matter their sources, start by an absolute story of how things 'are'. This story cannot be justified since it narrates the beginnings which no beginnings preceded, the first word which nothing before was written, and in this way truth is related to myth, and every judgment of truth invokes some myth. Thus myth runs deeper into the political and social experience of humans since it lies at the base of every human judgment on the world. That's why every endeavor to demystify the socio-political world will lead inevitably to new forms of mystification. Man cannot but live meaningfully, he needs judgments, that's why he needs criteria and a myth at their base. Examples for re-mystifications as a consequence of demystification are many such as the Marxist endeavor to sink religion deep in the cold water of rationality led to the march of history as a new myth put to replace the divine providence and the natural law (Engels and Marx 2010). Also Nietzsche's superman was put instead of the dead god and Hobbes's leviathan emerging out of some imaginal state of nature was put instead of the absolute church divine mission (Nietzsche 2006, Grant 2009). So myth is imperishable since it solely can justify human experience, choices and, by and large, the human existence (Stevanovic, 2008: 34). Therefore, man lives not with but through myth (Grant 2009: 27). 


\section{Approaches to the Study of Political Myth}

Varied are the approaches to the study of political myth. The paper divided these approaches into four main approaches: the conservative, the radical, the instrumental and the epistemological. They are named approaches since they have a vision for what myth is, what it does to society and how myth could be understood as a phenomenon.

\section{The Conservative Approach}

The conservative approach claims that the role of political myths is to help stabilize and harmonize the community and the political system. Within the conservative approach stands Emile Durkheim who believes that myth and religion are created to support the status quo and enhance solidarity and social cohesion (Tamse 1975: 6). While Karl Manheim believes that both ideology and myth play a role in the rationalization of the status quo. For Manheim, myth expresses the irrational endeavor for preservation, and ideology gives it a rational form (Manheim 1954, Morong 1994: 10).

Malinowski might uniquely represent a link between the conservative and the radical approaches to myth. Malinowski claims that myths justify the existing order by offering a model that suggests a continuity between the present and that model, and in this sense one respects his reality since it represents a continuity or a resemblance with some past on a mythological level and that reality has to keep following that level to legitimize its sustenance. Consequently, myth not only preserves, but also encourages innovating a certain track for the future (Malinowski 1954: 176, Tamse 1975: 6-7).

\section{$\underline{\text { The Radical Approach }}$}

The radical approach includes thinkers and social scientists who believe in the constructive and revolutionary role of myth. They either claim this explicitly or they are understood to support such a vision. Primarily among them is Geroge Sorel who thought that myths can arouse an enthusiasm necessary for a class or nation in combat with the existing order (Tamse 1975: 9). This necessary myth consists of images imbued with emotions, will and a vision of a new world and a new human role after the conversion to the belief of such myth (Tamse 1975, Sorel 2004). Also Fredrick Nietzsche sought explicitly from his Birth Of Tragedy and implicitly through his Superman in Zarathustra to restore the role of myth in enhancing and emancipating man from his current condition (Nietzsche 2007). Karl Marx, though implicitly, offered the myth of the march of history as a guide for the revolutionary class to change the world for a better place (Engels and Marx 2010). 


\section{The Instrumental Approach}

The instrumental approach treats myth uniquely as a tool that is useful (or operational) to achieve various things and different roles depending on the situation. These roles need not to be strictly radical or conservative since myth can actually do both. For Plato myth can mean and do different things. Myth can be a message transmitted from a generation to generation to keep the memory of society (Grant 2009: 20). In Phaedo it is also curative for the individual because telling and retelling myth can invoke better behaviors and stop improper ones (Plato 2016, Grant 2009: 21). Moreover, myth is the preamble of laws that justifies their formulations. Finally, myth can be a model for preferred arrangements that regulates the foundations of a real city in the future and the myth would be the paradigm for such an endeavor (Grant 2009: 21). The medicinal noble lie is one of the famous platonic examples in this respect (Plato 2000). Also, John Mbiti the African philosopher and theologian argued that the mythological conceptions a society has of some perfect Eden times can play a double role in conserving the cultural and social arrangements that underscores such conceptions. Also at the same time these conceptions of perfection provoke a reformist attitude against reality in order to be make it close to the images imbedded in the perfectionist conceptions (Mbiti 1971). Finally, for Mircea Eliade the concept of the 'Sacred time' represents the mythological ideals one yearns for, while our life and history are profane times that are encouraged to be more close to these sacred times (Eliade 1959).

\section{The Epistemological Approach}

The epistemological approach treats myth as a phenomenon that influences the conditions through which man understand and knows the world and politics. Myth enables man to make sense of his world, orient him and introduce some order to the chaotic manifestations of his reality. Claude LeviStrauss, though a structuralist, can be considered in this approach. Strauss considers myth to be providing an explanation for a phenomenon that we cannot understand otherwise (Levi-Strauss 1955: 429). The purpose of myth therefore is to provide a logical model capable of overcoming a contradiction (Edelman 1998: 133). Also Clifford Greetz believes that symbols usually tied mythically to meanings are important to relate facts to values, and thus make sense of the world by giving a world view that demands a certain morality (Greetz 1973: 127, Morong 1994: 19).

Blumenberg, in addition, starts from an idea that the existential anxiety man feels in a world whose conditions are not under his control makes him creates some powerful imaginal magnitudes. These magnitudes can be comprehended and help eliminate his fear by some procedures man must undertake (Blumenberg 1985). One example of the magnitudes that man imagined and created to control his reality and eliminate his fear was the state (Grant 2009: 23). Edelman, on the other hand, argues that myth help humans to cope with widely shared anxieties, but typically fails to analyze problems adequately and rarely solve them. Yet 
the very dependence of the citizens on their government to ward off evil makes them more susceptible to a political myth of the ability of the government to fight evil and eliminate anxiety, they then believe in the political myths offered by their government in different forms (Edelman 1998: 131).

From these different approaches, the circumstances for the emergence of myth, the functions of myth and the elements could be grasped. This is the occupation of the coming sections.

\section{The Circumstances for Myth Emergence}

Myths in general, and political myths in particular, are debatable topics when it comes to their spontaneity/artificiality of their origins. While some believe that myth is a spontaneous phenomenon related to the human condition (Grant 2009), others believe that myth is an artificially created phenomenon (Sorel 2004), and else believe it could actually be both depending on the situation and the consciousness of the mythical subject and whether he is aware of being subjected to myth or not (Stevanovic 2008). Therefore, the circumstances for the emergence of myth differs according to one's vision of the spontaneity/artificiality of the myth. The paper sorts out four kinds of circumstances for the emergence of myth and classifies them to be: dispositional, orientational, contextual, pragmatic and reactive.

\section{The Dispositional Circumstance}

This circumstance indicates that myth by itself emerges spontaneously due to the very mythological disposition in mankind. Hans Blumenberg and David Grandt claim that the situation of anxiety associated with the human experience of an uncontrollable reality impels man to imagine myth and become mythical. The human feeling of inability to control the forces of reality makes him spontaneously imagine mythical magnitudes of some forces that are able to stabilize, give a clue and tame this reality in his favor. Man lives through myth. Otherwise, reality would be terribly worrisome and terribly fearsome, reducing man to complete passiveness and a deep feeling of horror (Blumenberg 1985, Grant 2009).

\section{The Orientational Circumstance}

The orientational circumstance assumes that man by his nature is objective and tends to seek some goal, his very objectiveness compels him to seek some orientation in the form of an 'ideal' to follow and fulfill. Man cannot live without ideals/goals for which he dedicates his everyday endeavors. This need for orientation makes man seeks some way of life within which yearning for some paradise is formulated into a mythical tale. He endeavors for it in his diverse activities in society and politics. Eliade (1959) and Mbiti (1971) hold this vision of the need for orientation that leads to the emergence of myth. Both claim that such an orientation towards the eternal times, the nostalgia for past 
unlimited happiness, the pleasure of serenity and goodness of the ancestors days orient men and rescue them from the meaningless repetition of the profane/historical times within which man feels the burdens of his imperfection and pains.

\section{$\underline{\text { The Contextual Circumstance }}$}

The contextual circumstance indicates that certain contexts are riper than others for the emergence of myth. The ripest context for the emergence of myth is the time of crisis, when social reality becomes complicated, ugly and stressful to the extent that it impels people to yearn and accept unconventional accounts that promise for a better reality. Times of economic and social tensions are the grounds upon which political myth usually spreads (Stevanovic 2008: 34, Cassirer 1946: 288). Mythological accounts of the coming savior, the charismatic leader, the impending collapse, the end of the world and the punishment of god are but few examples for myths, hopeful and hopeless, that emerge at the times of crises.

\section{$\underline{\text { The Pragmatic Circumstance }}$}

The pragmatic circumstance indicates that the narrow and limited goals of politics invite the creation of myth either for preserving the status quo or changing it. Plato as mentioned before can be included. A more clear and brilliant account in this regard is the work of the Ethiopian Amasrom Legesse. Legesse, while studying the Borana Oromo nation in Ethiopia and its religious figure 'the Qallu', indicated that the necessity of creating a myth for the sublime origin of the Qallu emerges from the need for assuring the various tribes that he is neutral. Also the myth of sublime origin creates a distance between him and his subjects which maintains his neutrality because at the end of the day the Qallu is from one or another family in the community and nothing can prevent doubts that he might favor his group other than a sublime myth of his unique origin. The expedience of the founders made them create the habit and the myth that the origin of the Qallu have to be always unique and sublime, so that a distance between him and the rest of society including his own social group could be drawn and his neutrality could be guaranteed. Such a mythical account of origin can take the form of a heavenly descent of the Qallu, or an unconventional arrival to earth and to the tribe. The need for stability in power relations impels politicians to publicize some kind of myth to sustain their distance from the group and the masses to whom they belong (Legesse 1973: 46).

Moreover, political myth can be used pragmatically to inspire changes. Here myth can take the form of a political religion that encourages its believers to change the evil situation and effectuate the good community they dream for. George Sorel as mentioned before represent such a vision of myth as a political religion needed for the revolutionary group (Sorel 2004). 


\section{The Reactive Circumstance}

According to this circumstance, myth emerges out of the endeavor to cancel it. In other words, when the social agents try to demystify the social sphere, they cannot but re-mystify it by invoking a new myth in place (Stevanovic 2008). The illusions of prophets' revelation were replaced by Spinoza's natural right based on an imagination of a state of nature (Spinoza 2007). Nietzsche's god was replaced by the promise of a totally other reality that can take place at the hands of the superman (Nietzsche 2006). The idea of religion was renounced and replaced by the Marxist historical march (Engels and Marx 2010). The absolutism of the church was replaced by another absolute magnitude of the modern state for Hobbes (Grant 2009: 13). Therefore, according to this vision, myth emerges as a reaction to the action of canceling it. By default, such a vision of myth assumes that man by his nature has a mythological disposition to create and recreate myths.

\section{Functions of Myth}

A plethora of functions can be deduced from the various approaches, features and circumstances of myth but it would be more clear and distinct to order them into categories because otherwise myth would look like doing all the things for all people. The categories for myth functions are: existential, epistemological, conservative and reformatory. However, it should be noted that each category does not exclude the functions of the other because the mythological phenomenon is very complicated and the borders among such functions are usually blurred. But for the sake of clarity these functions have to be outlined separately.

\section{$\underline{\text { The Existential Functions }}$}

Existential functions are functions fulfilled by the political myth to meet the needs imposed by the existential condition of man. Melteniski argues that man's purpose from myth is to transform his existence 'from chaos to order' or cosmos (Meletinsky 1998: x). Moreover, myth prevents the situation of doubt, incoherence and disorder that man encounters or may encounter in reality. David Grant and Blumenberg, as before indicated, argue that the existential anxiety of man in an uncontrollable reality impels him to imagine magnitudes of power that will help stabilize his reality, eliminate his fear and symphasize with him (Grant 2009: 40, Blumenberg 1985: 50). These imaginal magnitudes of power are political myths par excellence.

\section{$\underline{\text { The Epistemological Functions }}$}

Myth offers symbols that enable us to understand the data collected from reality and judge them according to these symbols in a meaningful way. The huge amount of data one collects daily wants a 'danda' in Stephen peppers terms to interpret them (McDonald 1969: 145). This construct 'danda' measures the degree 
of conformity of this data against it. Any making sense of the world depends on such a 'danda' construct that tend to pose itself as absolute criteria for judging what is sensible and what is nonsense. Clifford Greetz claims that these sacred symbols of mythological background 'identify facts with value at the most fundamental level', they offer meanings to experiences (Greetz 1973: 127, Morong 1994: 19). Levi-Staruss also declares that the purpose of myth is to provide a logical model capable of overcoming a contradiction' (Levi-Strauss 1955: 429, Edelman 1998: 133). Therefore, Myth by its symbols -which relates causes to effects and facts to values- enables one to comprehend, make sense and judge reality in general, and make sense of and judge political reality in particular. 'Without myth ; language, human relations and power would be inefficacious' since there would be no categories of good/bad, meaningful/meaningless, true/ false that allow one to conceive things meaningfully (McDonald 1969: 144).

\section{The Conservative Functions}

Among the main, if not the most primary, functions of political myths is to justify the existing order, harmonize the social existence and maintain the status quo. Durkheim, Meleteniski and Manheim, as indicated earlier, all agreed on this point to various degrees (Meletinsky 1998: x, Manheim 1954). Karl Marx also with his conception of the attributes of superstructure-ideology can be understood to give myth a role justifying the wholesome relations of the socioeconomic existence (Marx 1999).

\section{The Reformatory Function}

Since Plato with his noble medicinal lie, the use of political myth was expedient to recommend preferable political behavior (Plato 2000).From a radical/ reformist point of view, myth can be 'created' or 'employed' to effectuate change of the existing order. Also myth by its orientation to some glorious past or promising future encourage changing and reforming reality towards more better conditions (Eliade 1959, Sorel 2004, Stevanovic 2008).

\section{Types of Myth and the Foundation Narrative}

From the previous presentation one can infer different types of political myths. These types could be inferred from the functions and circumstances of myth emergence. One could enumerate types like existential myths (Blumenberg 1985), conservative myths (Manheim 1954), revolutionary myths (Sorel 2004), operational myths (Plato 2000), reactive myths (Grant 2009), in addition to foundation myths which is the focus of our paper and is termed also as foundation narrative. Such a change in terms is due to studying foundation political myths in the discourse of politicians. At this moment myth becomes formulated as narrative at the hands of the political actor.

Although each type of myth has its own significance, foundation narrative is chosen more than else due to its having a more practical significance than the 
rest. Existential, conservative, revolutionary, reactive and operational myths are general terms that explain the different formulations of political myth. Yet by putting the political myth into time and place, political myths could start to have practical and analytical significance. Foundation narratives can be considered as this type of political myths placed into a certain time (foundation) and place (state). Such placing of myth in time and place requires from researchers to justify choosing this certain time and this certain place when analyzing political myth(s) of a certain context.

This paper chose the moments of state foundation as time and the discourse of state founders as place for its analytical horizon. Such a choice can be justified by different reasons. Place-wise, the paper argues that the state continues to be the fundamental phenomena for the study of politics. Temporally, the rise and fall of states (republics and political regimes as well) are one of the most dramatic events in the political history of any nation. However, choosing the moment of foundation has more practical significance than the moment of collapse. The paper argues that analyzing the foundation narrative formulated by state founders offers an insight into their values and their vision of the future. As shown above and would be shown next in illustrating an analytical framework for the study of myths, political myths are charged with systems of morality and an account of time. The practical significance of extracting such notions from the foundation narrative of a certain political agent/founder is that it enables one to judge the consistency between the politician's practice and discourse as shaped in his founding narrative and it also allows one to explore which vision of the future such a political actor has in mind. These two elements allow political analysts to judge better the discourse and the visions of state founders and political agents. Also for a dramatic moment like an emergence of a state (a republic or a political regime as well) allows a more clear view of the messages communicated by the state founders.

Historical research too can benefit from studying foundation narrative, as such a narrative can be used as a benchmark to assess the later practices of a certain political agent or ruling elite. For the above reasons, placing political myth into the time of foundation and the place of the state makes the foundation narrative a legitimate quest in our paper. In addition, and for more clear understanding of foundations narratives, the paper will try to employ its analytical framework in studying the consecutive narratives of the Egyptian state and understanding its current narrative crisis.

\section{An Analytical Framework for Political Myths and Foundation Narratives}

To better analyze any phenomenon, one has to deconstruct this phenomenon into its simplest parts, understand it nature and the interrelations among these parts, then re-construct it again. To put it simply, for one to analyze political myths there are certain elements that one has to explore in the myth. In addition to exploring these elements the relations between these elements have to elaborate. This section outlines these fundamental elements for analyzing political myths (and foundation narratives included) with an exploration of their interrelationships 
when possible. The elements of myth vary according to the structure and the content of each myth, yet -in general- political myths have some common elements that could be gathered from the diverse literature on myth. They are, inter alia, the following elements:

\section{Target and Reference Groups}

Political myths target social groups since myth could not be political if it did not spread and gain some ground in the world of men. And the extent of myth acceptability varies according to its ability 'to ignite' political expectations in its target groups who will be its social force (Stevanovic 2008: 34). In the myth this target group is oriented towards the ideal of some symbolic reference-group whose way of life and values are the wishes of the target group. For example, in national socialism there is the 'actual people' target-group whom the Fuehrer will move to be more like 'the true people or Folk reference group' which the target group wishes and endeavor to resemble (Harmon 1994: 449). Yet reference groups in political myths need not to be attainable or be imitated perfectly in reality. However, their importance to the myth lies in their symbolic power of orienting the target group to the ideals of the myth.

\section{A System of Political Morality}

Myth usually has a system of morality that defines what is good, who is good, what is evil, and who is evil. These are translated into some descriptions of the preferable political behavior, the best way of life, the rejected, criminal, immoral or traitor behaviors, and most importantly, the enemy or the threat or the challenge that the target group is destined to face (Morong 1994: 17) .

\section{$\underline{\text { An Account of Time }}$}

Political myths usually narrate and offer some account of time, how things started to be, how the end would look like and the possible trajectories of time, one preferable and the other avoidable. The choice of one trajectory over the other depends on the system of morality outlined by the myth. Therefore myth contains elements of cosmology (beginnings), epistemology (symbols), axiology (morals) and chronology of time according to its own mythological narration of events.

\section{A System of Causality and Responsibility}

Each political myth has its own system of causality. This system is very unique and needless to be suitable to any prevalent relations of political causes and effects because myth as such claims to be the narrator of the truth and therefore needs no justification. It needs not to adopt the framework of the inferior reality which it is invoked against. That's why different myths have different unique internal relations between causes and effects of the same phenomenon 
(Stevanovic 2008: 27). Each myth differs according to its system of causality, its morality and mission. Myth dictates 'which causes what' and the consequences of different political behaviors.Associated with this system of causality there is a system of responsibility stating who is responsible for which good/bad/evil conditions that occurred and who is responsible for the set of actions needed to be taken'.

\section{The Divine Mission}

Usually political myth indicates a mission for the agents targeted by its story. It outlines the actions needed to be done either to reach the endeavored goal, or to prevent the impending collapse, or at least shows how to adapt oneself to the course of events. This mission is 'divine' in the sense that it reflects the utmost wisdom, the best/truthful comprehension of the situation and the best choice to be taken and never to be negotiated. Who would negotiate a divine message!

\section{Egypt: A Long History of Foundation Narratives}

After outlining this detailed theory for the different instances of myth, political myths (including foundation narratives) and how to analyze its diverse elements and understand their interrelationships, it is important to put such efforts into practice by focusing on a certain case study. For this reason, the paper will try to analyze the consecutive crucial foundation narratives in the political history of Egypt and understand the crisis of its current narrative.

Egypt, one of the oldest civilizations in history, has a millenniums-old relationship with politics and the state. As well known, Egypt has one of the oldest 'unified' nation states. Although Egypt had witnessed different kingdoms, empires, colonialisms and republics with different rulers, there are important turning points in the political history of the Egyptian state. Important among them are Narmer's foundation of a unified Egypt ( $31^{\text {st }}$ Century B.C.), Mohamed Ali Pasha's foundation of modern Egypt (1805), the free officers Nasserite Foundation (1952), and Post-June 30, 2013 republic Foundation and the exceptional role of former General and incumbent president Abdulfattah Al-Sisy (2014-) in that foundation.

Aside from June foundation which is considered by some to be a 'restoration' not a 'foundation', the author chose the rest of foundations due to their quintessential importance in the formulation and reformulation of the Egyptian state. However, June foundation is studied to engage these analyses of past foundations with some contemporary narrative of foundation.

As a matter of fact, history is narratives since the same event can never have an unanimous reading across time, place or among historians and politicians. What is of importance to the current task is how each state founder (or probably group of founders) tries to narrate his own story his own way. In such a story he aims to communicate some ideas and values to be learnt and cherished. Not only values, 
but also his vision for the future could be understood by his contemporaries and later historians could assess his consistency accordingly.

Narmer (sometimes Menes Narmer) is credited to be the first king who founded a unified Egypt and established the first dynasty. Narmer's narrative is usually extracted from his famous palette in which he was depicted on the two sides of the palette wearing both the crowns of the north and south kingdoms of Egypt indicating his success in unifying the south and the north of Egypt by force and how this was celebrated by Gods. The foundation narrative of Narmer is an excellently complete example for a foundation narrative. First of all the narrative is a mythos par excellence, it is imbedded into a divine atmosphere. Included in it are all the elements one can need; The hero (Narmer), an account of time (battles of unity, and processions of glory), a target group (people of Egypt), a system of morality (the glorification of unity, victory and force and the denouncement of disunity, defeat and weakness), a system of causality (Narmer is the cause of unity), a system of responsibility (Narmer was responsible for unity and his defeated enemies were responsible for disunity) and the morale of this story was always the importance of unity for the Egyptians and the glorification of the leader who is usually a military leader (Wikinson 2000).

This leader was capable of achieving unification not simply by his wisdom but by his force and military victories. From that foundation moment onwards the king, also the warrior, had been glorified by Egyptians to the extent of worshipping. And the values that Narmer sought to communicate by his palette are up till now cherished by Egyptians and the Egyptian state. The values of unity and the supremacy of the king-the warrior is quintessential up till now in the Egyptian politics and political culture (Pratt 2005). Here one witnesses a myth that outlined a set values in the story of foundation and that myth succeeded to maintain influence on the founded state for millenniums to come in the future.

Another crucial turning point in the history of Egypt- and the most important turning point in its 'modern' history- is the foundation of modern Egypt by Mohamed Ali Pasha whose reign covered the period 1805-1848. Ali (1769-1849) founded a modern Egypt in the sense of establishing a state on the western style structure of government that contains ministries (dwaween), clear division of political and administrative roles, a bureaucracy, a professional organized army and all were controlled by one secular ruler. Yet the paradox of Mohamed Ali is that he represents the opposite of Narmer. Menes Narmer founded Egypt as a heroic king glorified by the gods and Egyptians, and communicated a set of values that has to be cherished by the posterity but Mohamed Ali's foundation was to a large extent empty of any heroic spectacles. Ali, not an Egyptian, had outmaneuvered all his political rivals until the Ulema, (Muslim clergy and local chiefs) deceived by his pretending political selflessness, delegated him with power. To make it worse, the establishment and the consolidation of his power was associated with a massacre he committed against the Memlukes, his remaining political rivals, whom Ali with his known shrewdness invited to his Citadel and in a single event staged a slaughter against them killing most of them (El-Sorbony 1926). The paradox of such modern Egypt is that it has no foundation narrative; it was founded on no heroism and no clear set of values from the 'beginnings' 
and such a lack of narrative didn't enable Ali to reflect to his subjects some clear vision of the future. On the contrary, Ali's reign was established by political maneuvers in the atmosphere of deception, ambiguity and in the aftermath of a massacre. This gives no clear messages or values from the fonder to the state and the people. And gave modern Egypt no clear vision of a future it must endeavor for. This made Khaled Fahmy (2002) to argue that Ali was not a national hero in any sense of the word, he was just grafting an autonomous kingdom for his family out of the ottoman dominion. Not to mention that his inability to speak to the people was partly due to their illiteracy and his Turkish tongue. Such a lack of narrative might have exacerbated such a bleak vision of his intention.

Since Ali was credited to be the founder of modern Egypt, having no narrative, he was only praised for his achievements with no story of greatness apart from being chosen by the representatives of the people at one point because of his success in deceiving them. Moreover, Ali's advent to power was during a period in world politics famous for its secret alliances and secret policies. Ali in turn kept his intentions unclear especially in an atmosphere of international, regional and domestic multilateral political conflicts imbued with conspiracies (El-Sorbony 1926) .

Modern Egypt from that moment until Nasser's foundation showed no clear vision of any mission which its consecutive leaders could seek and fulfill due to the simple reason of the absence and the inability to make a foundation narrative since the founder days. One can attribute this inability to the language and illiteracy barrier, and other like Fahmy (2002) might attribute it due to Ali's lack of interest to make a narrative to the people, this people whom were merely the fuel of his expansionist endeavors. However, both ways one ends up with a foundation with no narrative, leading to a rule with no clear values or vision for the future.

The British occupation of Egypt (1882-1954) might have ignited the reactive sentiments of independence and nationalism (Hussein 1996), but once Egypt won that independence, there emerged a need for a new foundation narrative to fill the moral vacuum made by the absence of any morally inspiring foundation narrative since Ali. Only after a turn of a century and half since Ali, Nasser and his comrades from the free officers would offer such a narrative.

Coming to the 1952 free officers' popularly supported revolutionary seize of power, one can notice that the free officers- formally led by General Mohamed Naguib (1901-1984) while the real leadership was for Nasser- offered Egypt a new foundation narrative much needed since the days of Ali (Younes 2012). This time the foundation narrative (expressed in the seize of power radio announcement by Sadat in 1952) expresses the ability of the Egyptian young armymen who represent the sons of the fellahin (lit. Egyptian peasantry) to remove the corrupt king, oust his unjust Turkish speaking elite, fight imperialism and end the feudalist system. The foundation narrative of the free officers and later on of Nasser was complete. It had the hero (Nasser and the officers), the target group (the Egyptian people), an account of time (how Egypt was corrupted and defeated by traitors and colonial collaborators), a system of morality (the goals of independence, dignity, justice, democracy and the enemies of corruption, 
despotism, feudalism and imperialism). These enemies were represented as the ones responsible and the causes of the disease, treason and defeat. On the contrary, the army young officers- the sons of the poor Egyptians led by Naguib and later on by Nasser salvaged Egypt from them and restored its lost pride and wealth. This represents among other things the mission of fighting these enemies and the aim of achieving the goals of justice and democracy.

What was more unique in the Nasserite foundation narrative is the addition of a new mythological element to the narrative. That is the 'mythological reference group' whom the actual people should imitate. The reference group is 'The People' or 'The great people of Egypt', a concept which Nasser the leader formulated and his later successors consumed. According to such a formulation, the leader solely understands and comprehends the true characteristics of the People and accordingly moves the actual people, or in Sherif Younis's terms 'The population', to imitate that reference group of the People. The leader by his speeches and policies would move 'the population' in order to be 'The people' (Younes 2012: 237-243). The problem with this concept of an imaginary reference group is its vagueness and the monopoly of the leader in comprehending and dictating it. This enabled the Egyptian leaders through their personal discourse and the use of media to claim how should the actual people behave and act in order to be more worthy of the title ' the great people of Egypt'. Hitherto, the foundation narrative of Nasserite Egypt continued its influence at the hands of all his successors, each adding his own content to the structure of the narrative according to the circumstances.

However, such inheritance of concepts did not go smoothly, as ruptures are usually expected in any machination of power. During the aftermath of January $25^{\text {th }}$ revolution, a revolution dramatically defeated and contained by the military in two years, one can find instances where the Nasserite reference concept gets challenged. The supreme council of armed forces SCAF, that assumed power after the ouster of Mubarak on February 2011, was in the habit of issuing military announcements. Within these military announcements one can frequently notice the repetitions of two main phrases: (great people of Egypt) and (honorable citizens). Following social media at this period, one can find political activists, perceiving SCAF as a continuity of the ousted regime, frequently mocking their repetitious terms and their fantasy of the 'honorable citizen' whom they believed as only a manipulative term to deceive people into following their orders. Honorable citizens are the term reserved for those who follow SCAF and any conspiratory accusation reserved for challengers. Such a mock of cowed people by revolutionary activists made the term 'honorable citizens' associated with citizens complicit with governing authorities. A whole sarcastic series named 'the honorable citizens' finding resemblances of the pro-authority complicit behaviors of such 'honorable citizens' in the history of Egypt was broadcasted on YouTube by some anti-regime Facebook page (5anah 2018). 


\section{The Post-June 30, 2013 Egyptian Republic: The Narrative and the Future}

The June republic foundation narrative can be gathered among different sources from three fundamental speeches; the (June 30, 2013) announcement by the Egyptian military command as a reaction to the June $30^{\text {th }}$ nationwide protests rebelling against The Muslim brotherhood President Mohamed Morsy. The (July 3, 2013 ) speech by the then general and Minster of Defense Abdul Fattah Al-Sisy in which he declared the removal of president Morsy and the suspension of constitution after consultation with various national political forces. And the most important speech among them is the speech on July 23, 2013 in which general Sisy, later on president Sisy, addressed the Egyptian nation at the graduation ceremony of the military academy. The importance of that speech lies in the fact of its inclusion -for the first time since the ouster of Morsy - of a clear narrative for the political circumstances of the removal and what should be next. However, among these speeches and declarations still there are common themes that might help in constructing a picture for the narrative of such a republic, and explore the challenges and the future as drawn in this foundation narrative.

First of all, President Sisy contributed more than anybody else in formulating the foundation narrative for the June Republic due to his de facto leadership of all the political events in Egypt since June 30, 2013 until his inauguration as a president in 2014. However, this June republic narrative faces many challenges that might influence its comprehensiveness and; consequently, its vision for the future. The elements of the June republic narrative include: a target group (the Egyptian people, and more specifically the anti-Muslim brotherhood large segments of the Egyptian population), which means that the message to the target group gives two contradictory statements, one of hopeful expectations and the other of threats. The expectations are reserved for the anti- brotherhood segments and the threats to the pro-brotherhood. Yet these hopeful expectations are to an extent paradoxical. President Sisy (the hero of the narrative) founded the state by a call to combat the future threats posed by terrorists (whom he enlists the brotherhood among). In his famous military academy speech, Sisy addressed Egyptians 'to go out to the streets to authorize the army and police to combat terror and violence' (Al Nashaby 2013). His message is not relieving like the normal foundation narratives which usually claim victory, the end of threat and the start of a new hopeful episode. Sisy notes 'The situation was very dangerous' and the 'ousted president' was ruling in order to destroy the state', so Egyptians have to be ready on the occasion of violence to 'authorize the army and police in order to combat violence and terrors'(Al Nashaby 2013).The June republic narrative is born from threats. It promises no further than battles against peril, these battles in some speeches were chosen, in others were imposed.

Such a narrative born in an atmosphere of horror and need cannot communicate any values which can reflect the vision of the emerging state. Nothing could be understood more than the vague promise of making Egypt ad el donia (lit. as big as the world), which does not surpass the level of mere 
enthusiasm and propaganda and reflects no clear vision aside from the battle against terrorism (Al Nashaby 2013). It can only communicate a call for war, a call for mobilizing ceaseless efforts to go into the battle. While in fact, states throughout history were often founded after the finished battle; such finished battle usually narrates the heroism of the warriors who will turn on a new leaf and start a promising future. Yet the June foundation narrative narrates the heroism of the hero whose heroism is not complete but still in need of more battles, the hero is both a hero and an imperfect warrior. He embattled the threat yet the threat was not defeated by him and still looms in the horizon. One year after his inauguration and in his speech at the UN, the former General and the incumbent popular president stressed the threat of terrorism he was invited to fight (Masr 2015). This gives the impression that this republic was born in war and not as the habit of most states 'after' the war. In Such incomplete narratives no values could be extracted, only a future of future-battles could be grasped, President Sisy frequently through all his speeches stresses this war atmosphere which poses the question: how the June Republic would look like if understood according to its foundation narrative? In fact, it would look like a regimen still caught in war and in need for a future foundation narrative to conclude that war by describing some ultimate victory yet to be accomplished.

Another paradox in the June republic narrative is that the threat the nation has to fight is always unclear and usually described in the passive voice. For although the president clearly describes his enemies of the nation, he still point to some conspiracies and threats in the making. This was mentioned in all the three founding speeches pointing to Mo'amarat bi tohak (lit. some conspiracies in the making)'. He described 'these conspiracies as targeting the state institutions' and that 'the conspiracies against the state is big' which is re-mentioned again in President' words two years after inauguration (Nahar TV 2016). But it is not clear who is behind them, which indicates that the system of political morality is incomplete because the identities of the evil and the good and the lines between them are not clear. This is unlike, for instance, the clearly identified enemies of Menes's palette and the free officers' foundation speech. Also the system of causality and responsibility is incomplete since a huge part of the story is being narrated in the passive voice.

Moreover, the mission or the 'divine' mission as narrated by the founder does not call for certain behavior other than the delegation to fight battles and unity during these battles. President Sisy argues, 'it is not important to be hungry, what is important is to be like that, (showing his closed fist as a call for unity)'. It communicates that this mission is to be held in an atmosphere of peril and deprivation. All this reflects no value and outlines the huge challenge and ambiguity that June republic is going to face in the future. This ambiguous challenge is the lack of vision for future and the continuous living in a situation of war, these situations of wars usually demands temporary unconventional measures and continuously changing behaviors. One can simply see this unconventionality in the continuous imposition of emergency laws in Egypt during Sisy's reign. 
This means that if the June republic was not provided in the near future with any other foundation narrative, it would be always captive to the mood of emergency, arbitrariness and temporariness in all its actions. The challenge of the future is that its vision is absent from the beginnings. However, it might be the virtue of our analysis of foundation narrative is to reveal or explore how the discourse of politicians might uncover their visions and in turn enlighten the subjects under their rule of the challenges imposed by that rule. The June republic seems to be destined to live in the unconventional incomplete realm of continuous battles; such a realm absolves politicians from giving clear positive promises of reform and offers them pretexts to continually impose unconventional measures. These incomplete narratives invoke a sense of war in imagination and emergency in practice and between both rights are violated.

\section{Foundation Narratives and what to make of them?}

By now it might become clear that the study of political myth and foundation narratives can be of benefit for political theory and practice. Foundation narratives offer a very important material to understand the elements of discourse offered at the moment of foundation. This is not only a matter of getting information about beliefs held at exceptional moments, it also offers a benchmark for assessing the consistency between the vision elaborated at the moment of foundation and the later practices of the founders. Further research also can work on the idea of how the vision of the future offered at moments of foundations dominates the latter practices of founders and their successors. Can one claim that the foundation narrative dictates the trajectories of the future for the state? This is a question that merits historical studies and comparisons between various states narratives. What this paper offered is to link the potentialities of future with the possibilities outlined at the moment of foundations.

In addition, political practice can make use of studying political myths and foundation narrative. As outlined in the paper, the different formulations of political myths and foundation narratives reflect different intentions of politicians. Subjects of power and political activists can witness three types of founding elites: the first: an elite with a clear and complete narrative upon which this elite can be assessed and negotiated. The second: an elite with no foundation narrative and this entails that they are either a continuity with an existent discourse of power and they can be assessed upon this discourse, or their lack of narrative might be a sign of their lack of concern to communicate with masses. This was seen in Mohamed Ali's case and how such a type of founders-though seems obsolete by our contemporary criteria- still poses a challenge to a free society and an accountable authority. The third: an elite like June's elite, which is an elite with an incomplete myth that stresses the exceptional threat of the current moment and claims that this exceptionality requires unconventional measures, same as those taken at war. Narratives formulated in the passive voice and frequently eluding to some hidden agendas not only gives no clear vision of the future, but also call for a sacrifice for the sake of fighting an unknown threats. This type of 
incomplete narratives, unlike the obsolete previous type, poses immense challenge to public liberties and rights. A narrative that found a state 'within' the war not 'after' the war overwhelms its subjects with the feeling of horror and requires from them, in some Hobbesian melancholy, a total surrender of liberties.

Further research can also work on developing the elements of the analytical framework offered in this paper by employing it in different circumstances so that different formulations of political myth could be found and theorized. Such an attempt can be consolidated by linking the realities of different regimes narratives with the situation of freedom and rights in their respective societies.

\section{Conclusion}

Politics and myth is tied throughout history, since man can live only through an experience of some myth that guides his action in reality and offers him criteria for judgment. Foundation narratives is one among different formulations of political myths, it is a political myth that narrates the account of foundation by the political-community founders. It accounts for the foundation events and outlines the values they wish to communicate and the vision they are to pursue. In order to understand this, the papers outlined a much needed general theory for the study of the diverse instances of myth, including definitions, features, approaches, circumstances, and functions. Out of this theory for political myth an analytical framework for analyzing political myths and specifically foundation narratives is established. To put such analytical framework into place and time, foundation narratives are studied by focusing on the interesting Egyptian case. The long history of foundation narratives offered by the consecutive formulations of the Egyptian state was studies to analyze how each narrative projects a certain configuration of values, and vision for future upon which the discourses of political leaders can be judged as consistent or not. Though Egypt first foundation at the hands of King Narmer offered a complete foundation narrative, Modern Egypt suffered a narrative crisis since its foundation by Mohamed Ali was empty of heroic spectacles. That crisis was alleviated later only with the advent of the Nasserite Egypt and its narratives of the great people of Egypt and the army of the nation. The crisis began to reveal itself again with Post June 30, 2013 republic foundation. The dedication of the founder of this republic to fight terrorism represented the republic inability to establish a narrative of any victorious heroism that could communicate a vision for the future. The continuous absence of this narrative might expose this republic to a future of continuous arbitrariness, lack of vision and expose its citizens to the continuous vagaries of the unconventional sense of war. Such unconventionality absolves rulers from political responsibility and violates rights by invoking a sense of emergency.

\section{References}

5anah, FPA (2018) Selselat Al-Mowatonon Alshorafaa. The Honorable Citizens Series. Available at: https://bit.ly/2kpbZLL. 
Cassirer E (1946) The Myth of The State. New Haven: Yale University press.

Edelman M (1998) Language, myths and rhetoric. Society 35(2): 131-139.

Eliade M (1959) Cosmos and History: The Myth of the Eternal Return. New York: Harper \& Brothers.

Eliade M (1963) Myth and Meaning. New York: Harper \& Row.

Al Nashaby F (2013) Al Nuss Al Kamel Li Kalamat 'Al-Sisy' (The Complete Text of Al-Sisy's Speech). Al Watan News. Available at: https://bit.ly/2kPwMs7.

Benoit C, Bottici C (2010) The Myth of The Clash of Civilizations. New York: Routledge.

Blumenberg H (1985) A Work on Myth. Cambridge: MIT Press.

Cambridge COD (2016) 'Myth'. Available at: https://bit.ly/2lXmHtl.

Eliade M (1998) The Sacred \& The Profane: The Nature of Religion. New York: Harcourt, Brace and World.

El-Sorbony MS (1926) Tarikh Misr Al-Hadith (History of Modern Egypt). Cairo: Matba'et Darulkutub Almisriyya.

Engels F, Marx K (2010) Manifesto of the Communist Party. Marxists Internet Archive. Available at: https://bit.ly/1DLXo9b.

Fahmy K (2002) All the Pasha's Men: Mehmed ALi, His Army and the Making of Modern Egypt. Cairo: The American University in Cairo Press.

Flood C (1996) Political Myth: A Theoretical Introduction. New York: Routledge.

Grant D (2009) The Mythological State and Its Empire. New York: Routledge,.

Greetz C (1973) The Interpretation of Culture: Selected Essays By Clifford Greetz. New York: Basic Book.

Harmon MJ (1994) Political Thought from Plato to the Present. New York: McGraw-Hill.

Hussein T (1996) Mostaqbal Al-Thaqaafati fi Misr (The Future of Culture in Egypt), 2nd ed. Cairo: Daru-1-Maaref.

Legesse A (1973) Gada: Three Approaches to The Study of African Society. New York: Free Press.

Levi-Strauss C (1955) The structural study of myth. The Journal of American Folklore 68(270): 428-444.

Levi-Strauss C (1963) Structural Anthropology. New York: Basic Books.

Malinowski B (1954) Magic, Science and Religion and Other Essays. New York: Doubleday \& Co.

Manheim K (1954) Ideology and Utopia. New York Harcourt: Brace \& Co.

Marx K (1999) A Contribution to the Critique of Political Economy. Available at: http:// www.marxists.org/archive/marx/works/1850/pol-econ/index.htm (2 of 2) [23/08/2000 17:06:55].

Masr M (2015) Sisi Calls For UN Strategy Against Extremism. Available at: http://www. madamasr.com/news/sisi-calls-un-strategy-against-extremism.

Mbiti J (1971) New Testament Eschatology in an African Background. Oxford: Oxford University Press.

McDonald LC (1969) Myth, politics and political science. The Western Political Quarterly 22(1): 141-150.

Meletinsky E (1998) The Poetics of Myth. New York: Routledge.

Morong C (1994) Mythology, Ideology and Politics. Paris.

NaharTV A (2016) 'Howar Al Ra'ees Al Sisy Al Kamel Ma'a Al E'lamy Ossama Kamal (President Al-Sisy's Complete Interview With Presenter Ossama Kamal) [Video File]'. Available at: https://bit.ly/2klo7NO.

Nietzsche F (2006) Thus Spoke Zarasuthra a Book for All and None. Cambridge: Cambridge University Press.

Nietzsche F (2007) The Birth of Tragedy and Other Writings. Cambridge: Cambridge University Press. 
Oxford (2016) Myth. Dictionaries, Oxford. Available at: https://bit.ly/2m1Aoaw.

Plato (2000) The Republic. Cambridge: Cambridge University Press.

Plato (2016) Phaedo. The MIT Classics Archive. Available at: http://classics.mit.edu/ Plato/phaedo.html.

Pratt N (2005) Identity, culture and democratization: the case of Egypt. New Political Science 27(1): 73-92.

Schorer M (1959) The Necessity of Myth. Daedalus (Myth and Mythmaking) 88(2): 359-362.

Sorel G (2004) Reflections on Violence. Cambridge: Cambridge University Press.

Spinoza B (2007) Theological Political Treatise. Cambridge: Cambridge University Press.

Stevanovic, B (2008) From archaic to modern (political) myth: the causes, functions and consequences. Facta Universitatis. Philosophy, Sociology, Psychology and History 7(1): 25-41.

Tamse CA (1975) The political myth. In JS Bromley, EH Kossmann (eds) Britain and the Netherlands: Volume V Some Political Mythologies. The Hague: Martinus Nijhoff.

Wikinson TA (2000) What a king is this: narmer and the concept of the ruler. The Jounral of Egyptian Archeology 86: 23-32.

Younes S (2012) Nida' Alsha'b: Tarikh Naqdy Lil Ideolojiya Al-Nasseriyya (The Call of The People : a Critical History of Nasserite Ideology ). Cairo: Dar El Shorouk. 
